Science, Technology and Development 35 (3): 131-140, 2016

ISSN 0254-6418 / DOI: 10.3923/std.2016.131.140

(C) 2016 Pakistan Council for Science and Technology

\title{
Groundwater Contamination in District Nowshera, Khyber Pakhtunkhwa, In the Wake of Super-flood 2010
}

\author{
${ }^{1,2}$ Iram Gul, ${ }^{1} \mathrm{~S}$. Shafiqur Rehman, ${ }^{1}$ Nosheen Hashim and ${ }^{3}$ Imran Ahmed \\ ${ }^{1}$ Department of Environmental Sciences, University of Peshawar, Peshawar, Pakistan \\ ${ }^{2}$ Institute of Environmental Sciences and Engineering, National University of Science and Technology, \\ Islamabad, Pakistan \\ ${ }^{3}$ Department of Geology, Bacha Khan University, Charsadda, Pakistan
}

\begin{abstract}
Khyber Pakhtunkhwa (KPK) was the most severely affected province in the monsoon flood of 2010. A total of twenty-seven water samples were collected, nearly two months after the flood, from Nowshera district and were analyzed for physical, chemical and biological parameters. Nearly all samples showed abnormally higher values for Electrical Conductivity (EC), hardness, alkalinity, Total Dissolved Solids (TDS), Total Suspended Solids (TSS), Total Solids (TS), Total Coliform Bacteria (TCB), Fecal Coliform Bacteria (FCB), chloride, sulfate, sodium, iron, lead, cadmium and nickel, therefore, water was not safe for human consumption. Some quality parameters, such as $\mathrm{pH}$ calcium, magnesium, nitrate, phosphate, chromium, copper and zinc, were found within permissible limits. This study was conducted to evaluate changes in the groundwater quality of district Nowshera in the wake of 2010 super-flood and to establish its relationship with wide occurrence of water-borne diseases.
\end{abstract}

Key words: Floods, Pakistan, Nowshera, KPK and water-borne diseases

\section{INTRODUCTION}

Pakistan received the most disastrous flood during 2010 monsoon, due to an extraordinary spell of heavy rainfall. One fifth of the country was flooded in the months of late July and early August (NDMA., 2011; Abid et al., 2010). The catastrophic flood brought destruction; dislocation of community and millions of acres of fertile land was submerged. National Disaster Management Authority (NDMA), mentioned in its report that 78 districts were affected in whole country, of which 29 districts were severely affected. The Khyber Pakhtunkhwa (KP) was the most severely affected province in the whole country, where 24 districts were affected, while Peshawar, Charsadda, Nowshera, Swat, Dir, D.I. Khan, Shangla and Tank were the most brutally affected (Chitrali, 2010).

Flood brought many problems in the study areas, such as, unavailability of safe and hygienic drinking water, medical facilities, food, clothes and shelter. Moreover, the groundwater reservoirs were contaminated with many pathogenic organisms, due to inflow of flood water into groundwater through open wells and infiltration through soil. Local community of study area mainly depends on groundwater and drill water through hand pumps, bore and well. The contamination of groundwater reservoirs and stagnant water, after flood in different districts, caused many water-related diseases, such as, cholera, dysentery, malaria and skin infection (Rehman, 2010).

\section{MATERIALS AND METHODS}

Study area: The study area is located along the banks of Kabul River with latitude from $33^{\circ}-41^{\prime}$ to $34^{\circ}-10^{\prime} \mathrm{N}$ and longitude from $71^{\circ}-30^{\prime}$ to $72^{\circ}-16^{\prime} \mathrm{E}$. The district covers an area of $1,748 \mathrm{~km}^{2}$, with 2342.5750 hectors agricultural land, 396.6400 hectares hectors of shrub, bushes and 87.7347 hectors of forest (Ahmad, 2009). The study area has two main rivers, namely Kabul and Indus River. The district has two perennial streams, namely Kalpani River, Bara River and many dry streams or "Khwars" (Fig. 1), which are responsible for serious destruction in rainy season.

The climate of study area is pleasant, receives $50.8 \mathrm{~mm}$ and $18.2 \mathrm{~mm}$ of rainfall in the month of July and August, respectively, but in 2010, an unexpected rainfall was recorded, which was eight to twenty times more than the normal rainfall (Fig. 2). This unprecedented rainfall in the district was the main cause of catastrophic flood in the area (PMD., 2011).

Filed survey: An extensive field survey was conducted in the flood affected areas of district Nowshera in 


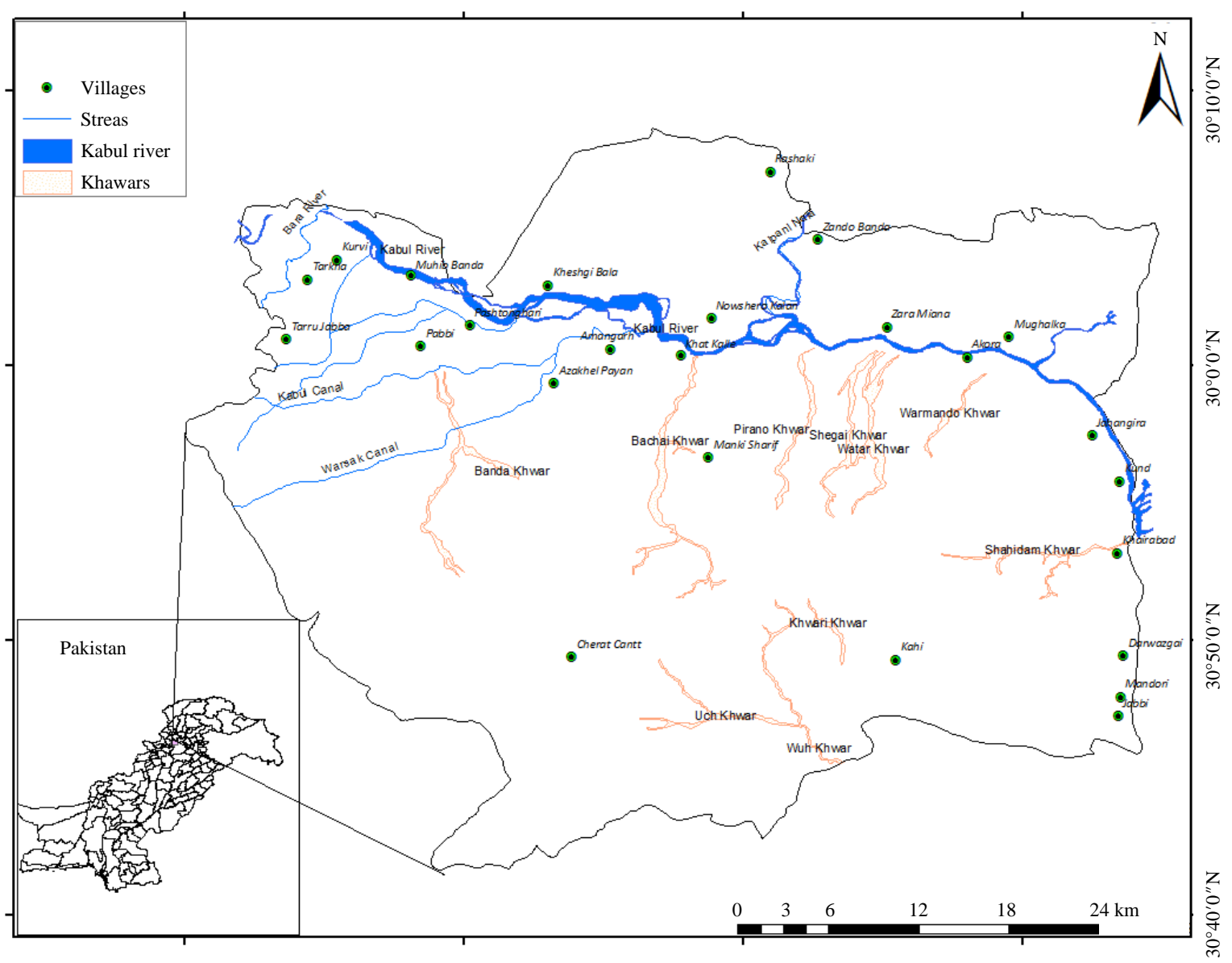

Fig. 1: Location map of study area (Nowshera), Khyber Pakhtunkhwa, Pakistan

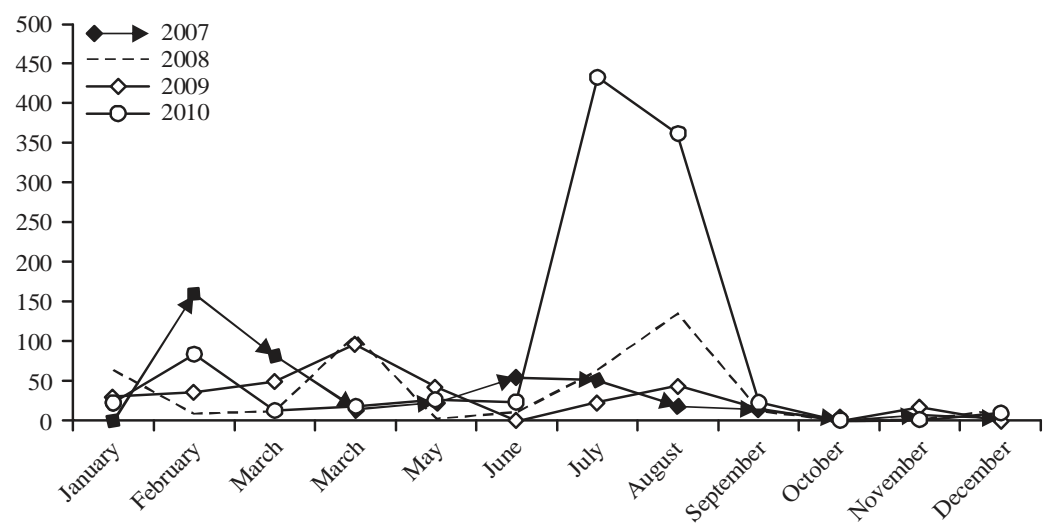

Fig. 2: Comparison of average rainfall in district Nowshera; from 2007-2010 (PMD., 2011)

October, 2010. During the field visit, interviews of the local communities and District Coordinator Officer (DCO) were conducted to assess the damage and destruction of property, agricultural land, groundwater quality and ensuing epidemics in the wake of super flood received in August, 2010. The data of water-borne diseases was collected from WHO (World Health Organization), Peshawar.

Water sampling: Nearly two months after the flood, grab samples were collected from tube wells, dug wells and hand pumps of twenty-seven different villages and towns 
Sci. Technol. Dev., 35 (3): 131-140, 2016

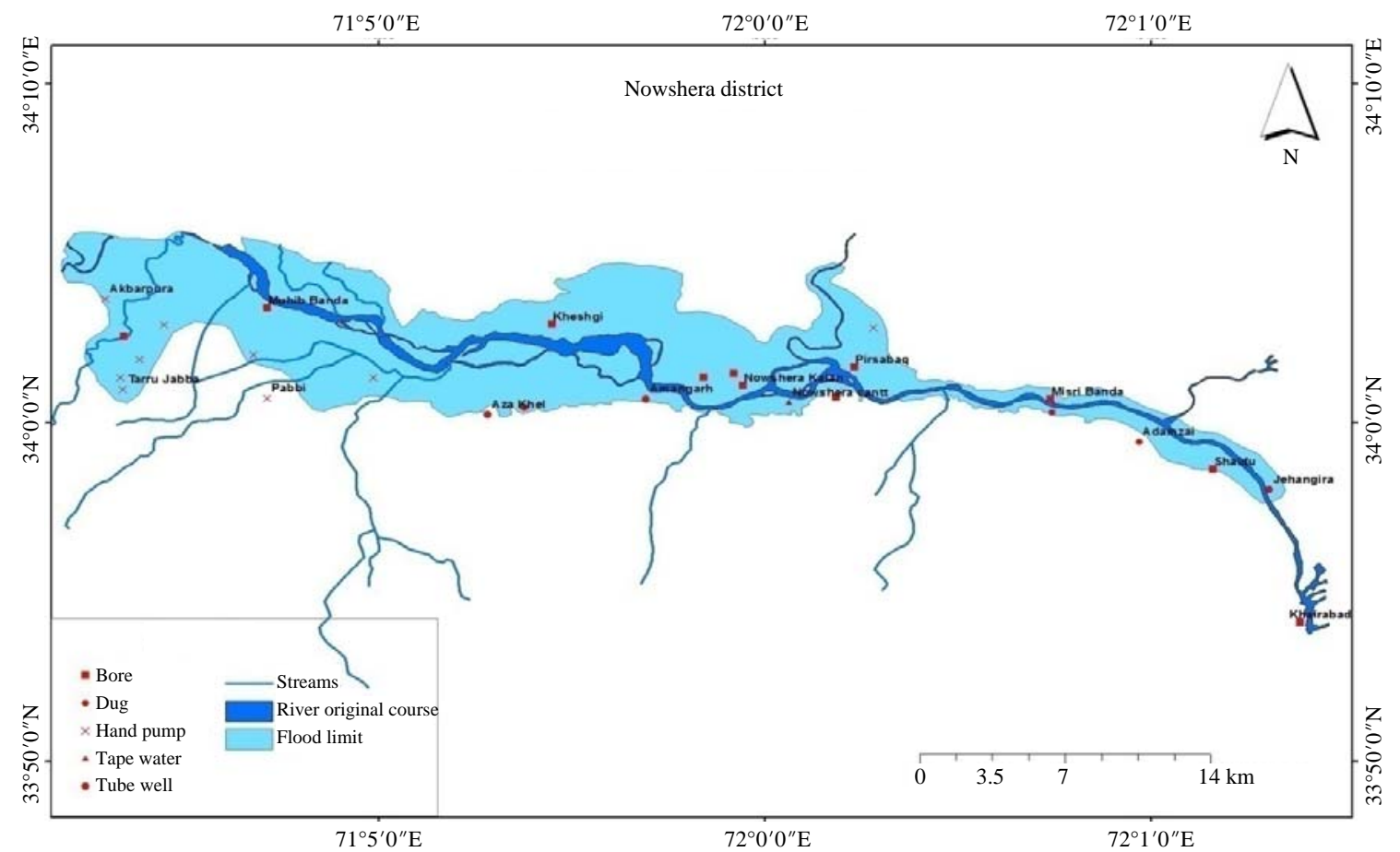

Fig. 3: Points showing sample locations with respect to water sources

on either side of river Kabul (Fig. 3). On completion of laboratory analyses of all the samples collected in October, 2010, eleven sites were selected for the second phase of sampling, based on abnormally high values of certain parameters in October, 2011. Three sampling bottles, two polythene bottles of $500 \mathrm{~mL}$ (physical and chemical analyses) and one sterilized glass bottle of $250 \mathrm{~mL}$ (biological analyses) were filled from each sampling site. All samples were analyzed for $\mathrm{pH}$, Electrical Conductivity (EC), Total Suspended Solids (TSS), Total Dissolved Solids (TDS), Total Solids (TS), turbidity, alkalinity and hardness. Different cations (sodium, calcium, magnesium), anions (chloride, nitrate, sulfate, phosphate), heavy metals (iron, copper, nickel, zinc, lead, chromium, cadmium) and biological parameters (total coliform, fecal coliform) were also analyzed through standard procedures.

Analytical procedures: All the physical, chemical and biological parameters were analyzed, using standard methods (Arnold et al., 1992). Some parameters, such as, $\mathrm{pH}$ and EC, were analyzed on the spot. $\mathrm{pH}$ was determined through Jenway $350 \mathrm{pH}$ meter, EC and temperature were determined through water quality checker (U-10 Horiba, Japan). The TS, TDS, TSS, alkalinity and hardness were determined through titrimetric method. Anions (sulfate, nitrate, phosphate, chloride) were analyzed through $\mathrm{HACH}$ spectrophotometer DR 2800 (Muhammad et al., 2010; Islam ud Din, 2011), cations and heavy metals were determined through Perkin Elmer Analyzer 700 Atomic Absorption Spectrophotometer

(AAS) (Muhammad et al., 2011; Gul, 2011).

Statistical analysis: Microsoft excel software (Microsoft 2010) was used to graphically represent the results and to calculate the means and standard deviations of the results obtained.

\section{RESULTS AND DISCUSSION}

Table 1 and 2 summarize the status of physico-chemical parameters of samples, collected in October, 2010 and October, 2011, respectively. The results of heavy metals and coliform analyses of both phases of sampling are given in Table 3-4. The data of water-borne diseases collected from WHO (World Health Organization) are shown in Table 5.

Physico-chemical characteristic: In the study area, $\mathrm{pH}$ value ranged from 7.25-8.3 and 7.7-8.1 for samples collected in 2010 and 2011, respectively. Samples, collected in 2010, showed high values of EC ranging from 0.418-3.90 $\mathrm{ms} \mathrm{cm}^{-1}$, however, in 2011, most of the samples showed EC within the range from 0.40-1.50 $\mathrm{ms} \mathrm{cm}^{-1}$. During both phases (2010 and 2011), 


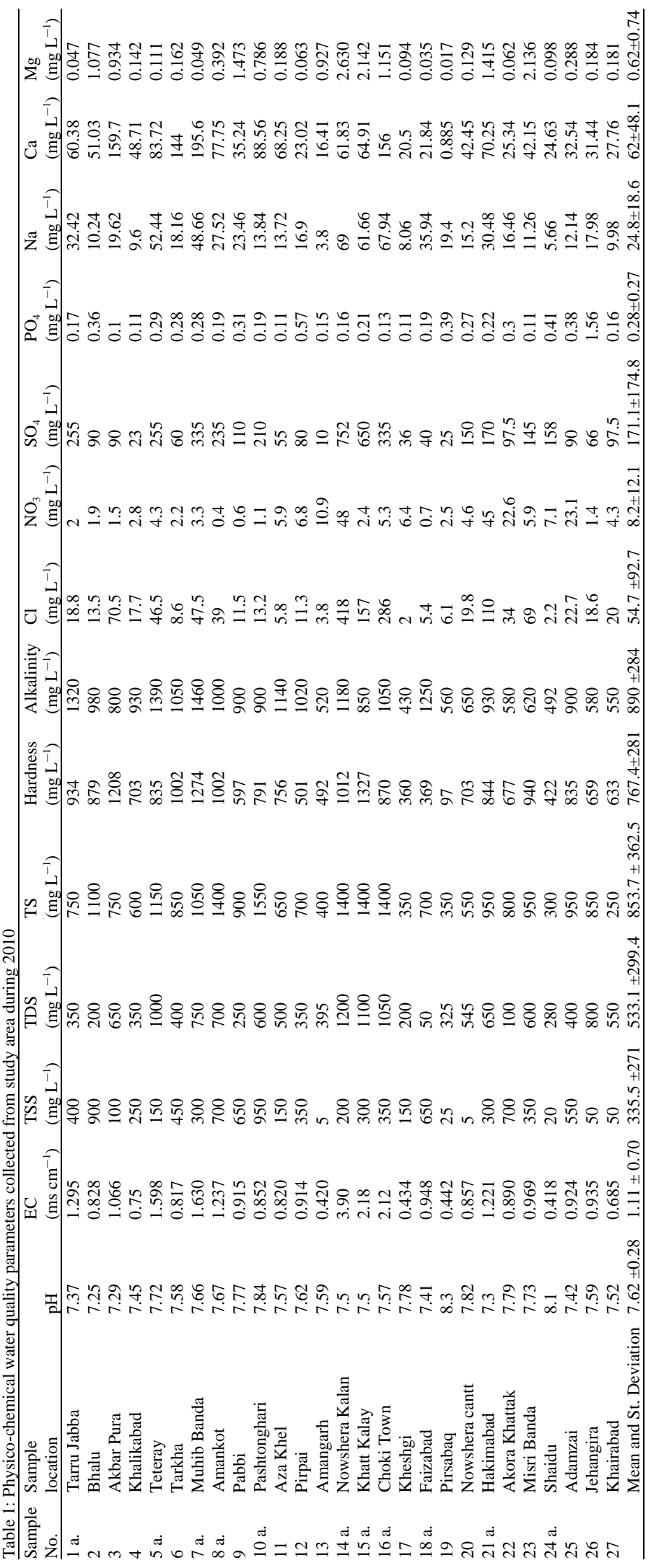


Sci. Technol. Dev., 35 (3): 131-140, 2016

Table 2: Physico-chemical water quality parameters collected from study area during 2011

\begin{tabular}{|c|c|c|c|c|c|c|c|c|c|c|}
\hline Sample No. & Sample location & $\mathrm{pH}$ & $\begin{array}{l}\mathrm{EC} \\
\left(\mathrm{ms} \mathrm{cm}^{-1}\right)\end{array}$ & $\begin{array}{l}\mathrm{TSS} \\
\left(\mathrm{mg} \mathrm{L}^{-1}\right)\end{array}$ & $\begin{array}{l}\text { TDS } \\
\left(\mathrm{mg} \mathrm{L}^{-1}\right)\end{array}$ & $\begin{array}{l}\mathrm{TS} \\
\left(\mathrm{mg} \mathrm{L}^{-1}\right)\end{array}$ & $\begin{array}{l}\text { Hardness } \\
\left(\mathrm{mg} \mathrm{L}^{-1}\right)\end{array}$ & $\begin{array}{l}\text { Alkalinity } \\
\left(\mathrm{mg} \mathrm{L}^{-1}\right)\end{array}$ & $\begin{array}{l}\mathrm{Cl} \\
\left(\mathrm{mg} \mathrm{L}^{-1}\right)\end{array}$ & $\begin{array}{l}\mathrm{SO}_{4} \\
\left(\mathrm{mg} \mathrm{L}^{-1}\right)\end{array}$ \\
\hline 1b. & Tarru Jabba & 7.7 & 1.18 & 2 & 666 & 668 & 650 & 700 & 7.3 & 245 \\
\hline $5 b$. & Teteray & 7.7 & 0.883 & 5 & 650 & 655 & 420 & 720 & 10.1 & 187.5 \\
\hline $7 \mathrm{~b}$. & Muhib Banda & 8.1 & 0.980 & 10 & 515 & 525 & 800 & 748 & 12.4 & 250 \\
\hline 8b. & Amankot & 7.7 & 0.848 & 20 & 680 & 700 & 735 & 525 & 7.5 & 187.5 \\
\hline $10 \mathrm{~b}$. & Pashtonghari & 8.1 & 0.55 & 100 & 1000 & 1100 & 450 & 475 & 10.2 & 180 \\
\hline 14b. & Nowshera Kalan & 7.8 & 1.50 & 50 & 1150 & 1200 & 750 & 450 & 230 & 450 \\
\hline 15b. & Khatt Kalay & 7.8 & 1.150 & 5 & 820 & 825 & 852 & 412 & 132 & 338 \\
\hline $16 \mathrm{~b}$. & Choki Town & 7.9 & 1.10 & 5 & 720 & 725 & 465 & 315 & 150 & 250 \\
\hline $18 \mathrm{~b}$. & Faizabad & 8.1 & 0.641 & 5 & 635 & 640 & 250 & 480 & 0 & 23 \\
\hline $21 \mathrm{~b}$. & Hakimabad & 7.8 & 0.70 & 3 & 747 & 750 & 425 & 525 & 35 & 165 \\
\hline \multirow[t]{2}{*}{$24 \mathrm{~b}}$. & Shaidu & 8.1 & 0.40 & 5 & 245 & 250 & 315 & 250 & 2 & 140 \\
\hline & Mean and St. deviation & $7.8 \pm 0.2$ & $0.90 \pm 0.32$ & $10 \pm 8.4$ & $693.4 \pm 208.5$ & $703.4 \pm 213$ & $555.6 \pm 207.9$ & $509.1 \pm 160.6$ & $54.2 \pm 78.8$ & $219.6 \pm 110$ \\
\hline
\end{tabular}

\begin{tabular}{|c|c|c|c|c|c|c|c|c|c|c|}
\hline $\begin{array}{l}\text { Sample } \\
\text { No. }\end{array}$ & Location & $\begin{array}{l}\mathrm{Fe} \\
\left(\mathrm{mg} \mathrm{L}^{-1}\right)\end{array}$ & $\begin{array}{l}\mathrm{Cu} \\
\left(\mathrm{mg} \mathrm{L}^{-1}\right)\end{array}$ & $\begin{array}{l}\mathrm{Ni} \\
\left(\mathrm{mg} \mathrm{L}^{-1}\right)\end{array}$ & $\begin{array}{l}\mathrm{Zn} \\
\left(\mathrm{mg} \mathrm{L}^{-1}\right)\end{array}$ & $\begin{array}{l}\mathrm{Pb} \\
\left(\mathrm{mg} \mathrm{L}^{-1}\right)\end{array}$ & $\begin{array}{l}\mathrm{Cr} \\
\left(\mathrm{mg} \mathrm{L}^{-1}\right)\end{array}$ & $\begin{array}{l}\mathrm{Cd} \\
\left(\mathrm{mg} \mathrm{L}^{-1}\right)\end{array}$ & $\begin{array}{l}\text { Total coliform } \\
\text { MPN/100 mL }\end{array}$ & $\begin{array}{l}\text { Fecal coliform } \\
\text { MPN/100 mL }\end{array}$ \\
\hline 1a. & Tarru Jabba & 0.054 & 0.007 & 0.037 & 0.033 & 0.316 & 0.034 & 0.028 & 550 & 550 \\
\hline 2 & Bhalu & 0.044 & 0.008 & 0.032 & 0.03 & 0.362 & 0.021 & 0.025 & 140 & 20 \\
\hline 3 & Akbar Pura & 0.041 & 0.009 & 0.027 & 0.032 & 0.386 & 0.023 & 0.024 & 31 & 29 \\
\hline 4 & Khalikabad & 0.033 & 0.006 & 0.011 & 0.049 & 0.468 & 0.028 & 0.023 & 550 & 550 \\
\hline $5 a$. & Teteray & 0.03 & 0.03 & 0.058 & 0.035 & 0.904 & 0.004 & 0.018 & 16 & 12 \\
\hline 6 & Tarkha & 0.043 & 0.038 & 0.053 & 0.028 & 0.939 & 0.013 & 0.017 & 46 & 46 \\
\hline $7 a$. & Muhib Banda & 0.059 & 0.04 & 0.081 & 0.232 & 0.978 & 0.024 & 0.014 & 50 & 50 \\
\hline 8a. & Amankot & 0.232 & 0.044 & 0.055 & 0.044 & 0.998 & 0.024 & 0.013 & $1800+$ & 250 \\
\hline 9 & Pabbi & 0.023 & 0.047 & 0.069 & 0.053 & 1.039 & 0.026 & 0.018 & $1800+$ & $1800+$ \\
\hline 10a. & Pashtonghari & 0.18 & 0.001 & 0.058 & 0.145 & 1.067 & 0.015 & 0.014 & 2 & 0 \\
\hline 11 & Aza Khel & 0.507 & 0.035 & 0.079 & 0.044 & 0.903 & 0.005 & 0.018 & 47 & 25 \\
\hline 12 & Pirpai & 0.044 & 0.037 & 0.078 & 0.099 & 0.846 & 0 & 0.016 & 1600 & 1600 \\
\hline 13 & Amangarh & 0.021 & 0.038 & 0.078 & 0.05 & 0.795 & 0.005 & 0.015 & 25 & 25 \\
\hline 14a. & Nowshera Kalan & 0.564 & 0.003 & 0.007 & 0.057 & 0.58 & 0.041 & 0.021 & 550 & 424 \\
\hline 15a. & Khatt Kalay & 0.644 & 0.041 & 0.031 & 0.188 & 1.1 & 0.029 & 0.018 & 17 & 17 \\
\hline 16a. & Choki Town & 0.047 & 0.05 & 0.039 & 0.323 & 1.132 & 0.018 & 0.018 & 22 & 9 \\
\hline 17 & Kheshgi & 0.468 & 0.033 & 0.082 & 0.038 & 1.134 & 0.03 & 0.01 & 4 & 4 \\
\hline $18 a$. & Faizabad & 0.062 & 0.016 & 0.01 & 0.119 & 0.471 & 0.028 & 0.016 & 29 & 29 \\
\hline 19 & Pirsabaq & 0.013 & 0.015 & 0 & 0.045 & 0.495 & 0.035 & 0.013 & 14 & 12 \\
\hline 20 & Nowshera Cantt & 0.017 & 0.033 & 0.079 & 0.175 & 1.123 & 0.028 & 0.01 & 14 & 4 \\
\hline 21a. & Hakimabad & 0.012 & 0.018 & 0.039 & 0.055 & 0.583 & 0.032 & 0.013 & 152 & 115 \\
\hline 22 & Akora Khattak & 0.028 & 0.02 & 0.044 & 0.29 & 0.609 & 0.017 & 0.016 & 22 & 17 \\
\hline 23 & Misri Banda & 0.045 & 0.017 & 0.048 & 0.29 & 0.686 & 0.004 & 0.01 & 29 & 12 \\
\hline 24a. & Shaidu & 0.066 & 0.023 & 0.062 & 0.861 & 0.707 & 0.012 & 0.01 & 31 & 8 \\
\hline 25 & Adamzai & 0.031 & 0.035 & 0.053 & 0.034 & 0.788 & 0.001 & 0.012 & 7 & 4 \\
\hline 26 & Jehangira & 0.04 & 0.029 & 0.07 & 0.077 & 0.753 & 0.001 & 0.012 & 9 & 2 \\
\hline \multirow[t]{2}{*}{27} & Khairabad & 0.127 & 0.03 & 0.069 & 0.048 & 0.781 & 0.003 & 0.013 & 0 & 0 \\
\hline & Mean and St. deviation & $0.128 \pm 0.18$ & $0.026 \pm 0.23$ & $0.04 \pm 0.02$ & $0.128 \pm 0.16$ & $0.77 \pm 0.25$ & $0.018 \pm 0.012$ & $0.016 \pm 0.004$ & - & - \\
\hline
\end{tabular}

Table 4: Heavy metals and biological water quality parameters collected from study area during 2011

\begin{tabular}{|c|c|c|c|c|c|c|c|}
\hline Sample No. & Locations & $\mathrm{Fe}\left(\mathrm{mg} \mathrm{L}^{-1}\right)$ & $\mathrm{Ni}\left(\mathrm{mg} \mathrm{L}^{-1}\right)$ & $\mathrm{Cd}\left(\mathrm{mg} \mathrm{L}^{-1}\right)$ & $\mathrm{Pb}\left(\mathrm{mg} \mathrm{L}^{-1}\right)$ & Total coliform MPN/100 mL & Fecal coliform MPN/100 mL \\
\hline 1b. & Tarru Jabba & 0.034 & 0 & 0.010 & 0.058 & 8 & 8 \\
\hline $5 b$. & Teteray & 0.012 & 0.001 & 0.001 & 0.017 & 7 & 0 \\
\hline $7 b$. & Muhib Banda & 0.011 & 0.001 & 0.003 & 0 & 16 & 2 \\
\hline 8b. & Amankot & 0.009 & 0.001 & 0.006 & 0.066 & 12 & 2 \\
\hline 10b. & Pashtonghari & 0.013 & 0.001 & 0.001 & 0.019 & 8 & 0 \\
\hline 14b. & Nowshera Kalan & 0.013 & 0 & 0.006 & 0.005 & 150 & 45 \\
\hline 15b. & Khatt Kalay & 0.012 & 0.001 & 0.003 & 0.057 & 7 & 2 \\
\hline $16 \mathrm{~b}$. & Choki Town & 0.022 & 0.001 & 0.010 & 0.008 & 20 & 0 \\
\hline $18 \mathrm{~b}$. & Faizabad & 0.007 & 0 & 0.010 & 0.039 & 7 & 0 \\
\hline $21 b$. & Hakimabad & 0.011 & 0 & 0.010 & 0.047 & 7 & 2 \\
\hline \multirow[t]{2}{*}{ 24b. } & Shaidu & 0.009 & 0 & 0.001 & 0.047 & 8 & 0 \\
\hline & Mean and St. deviation & $0.013 \pm 0.007$ & $0.00054 \pm 0.00049$ & $0.0055 \pm 0.003$ & $0.033 \pm 0.03$ & - & - \\
\hline
\end{tabular}

Shaidu showed the lowest values and Nowshera Kalan showed the highest values of EC. In 2010, TSS calculated for most of the samples, which were above the permissible limit, ranging from 5-950 $\mathrm{mg} \mathrm{L}^{-1}$, only two sample locations, Nowshera Cantt. and Amangarh, showed TSS within safe limit. Conversely, most of the samples, collected in 2011, showed TSS within the safe limit, ranging from 2-100 $\mathrm{mg} \mathrm{L}^{-1}$. Sample collected from Pahtonghari showed the highest value of TSS. Both TDS and TS for samples, collected during the first phase, were ranging from 50-1200 and 250-1550 $\mathrm{mg} \mathrm{L}^{-1}$, respectively. Though, the TDS and TS were found to be within permissible limits, ranging from 245-1150 and 250-1200 $\mathrm{mg} \mathrm{L}^{-1}$, respectively, for most of the samples collected after one year of first sampling. 
Sci. Technol. Dev., 35 (3): 131-140, 2016

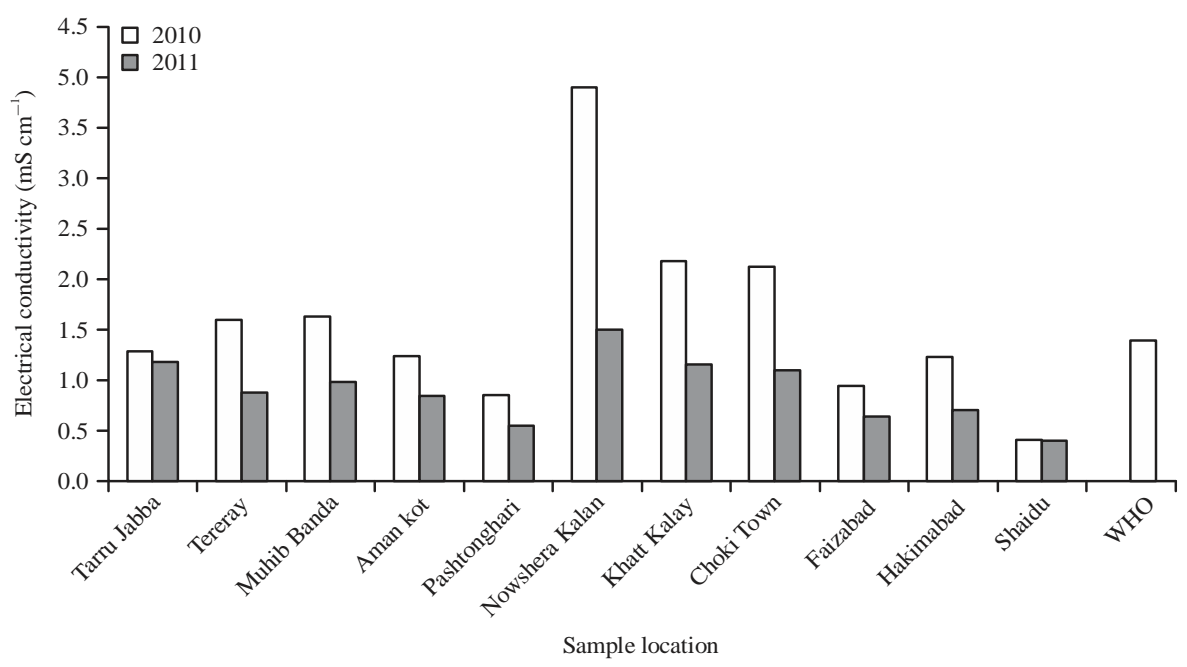

Fig. 4: Comparison of electrical conductivity of water samples of 2010 and 2011

Table 5: Cases of water borne diseases in the study area after 2010 Super-flood

\begin{tabular}{llllcl}
\hline Locations & Cholera & Dysentery & Malaria & Skin infection & Total \\
\hline Akbarpura & 818 & 0 & 105 & 923 & 1846 \\
Tarru Jabba & 1382 & 0 & 116 & 1498 & 2996 \\
Muhib Banda & 299 & 1 & 41 & 340 & 681 \\
Aman Kot & 470 & 42 & 54 & 524 & 1090 \\
Aza Khel & 447 & 1 & 0 & 447 & 895 \\
Kheshgi & 370 & 3 & 0 & 370 & 743 \\
Nowshera & 1569 & 16 & 132 & 1701 & 3418 \\
Pirsabaq & 328 & 3 & 2 & 330 & 663 \\
Misri Banda & 413 & 0 & 115 & 528 & 1056 \\
Akora Khattak & 739 & 70 & 29 & 768 & 1606 \\
Adamzai & 468 & 26 & 80 & 548 & 1122 \\
Shaidu & 409 & 0 & 16 & 425 & 850 \\
Jehangira & 413 & 6 & 46 & 459 & 924 \\
Khairabad & 509 & 0 & 30 & 539 & 1078 \\
Total & 8634 & 168 & 766 & 9400 & 18968 \\
\hline & & & & &
\end{tabular}

The values of hardness of first phase samples, ranging from $360-1327 \mathrm{mg} \mathrm{L}^{-1}$, the highest value (1327 $\mathrm{mg} \mathrm{L}^{-1}$ ) was observed for sample collected from Khatt Kalay and the lowest value $\left(360 \mathrm{mg} \mathrm{L}^{-1}\right.$ ) for Kheshgi. The values of hardness changed in the second phase samples, varying from 315-852 $\mathrm{mg} \mathrm{L}^{-1}$, the lowest value (315 $\mathrm{mg} \mathrm{L}^{-1}$ ) was observed for Shaidu and the highest value ( $852 \mathrm{mg} \mathrm{L}^{-1}$ ) was observed for Khatt Kalay. The samples, collected in 2010, showed higher values of alkalinity, ranging from $430-1460 \mathrm{mg} \mathrm{L}^{-1}$. The highest value (1460 $\mathrm{mg} \mathrm{L}^{-1}$ ) was noted for Muhib Banda and the lowest value $\left(430 \mathrm{mg} \mathrm{L}^{-1}\right.$ ) for Kheshgi. Teteray (1390 mg L ${ }^{-1}$ ), Tarru Jabba (1320 $\mathrm{mg} \mathrm{L}^{-1}$ ), Aman Kot (1000 mg L ${ }^{-1}$ ), Aza Khel (1140 mg L ${ }^{-1}$ ), Nowshera Kalan (1180 mg L ${ }^{-1}$ ), Choki Town (1050 $\mathrm{mg} \mathrm{L}^{-1}$ ) and Faizabad (1250 $\mathrm{mg} \mathrm{L}^{-1}$ ) showed abnormally high values of alkalinity. However, alkalinity values observed during the second phase of sampling, showed a remarkable decrease as values ranged from $250-748 \mathrm{mg} \mathrm{L}^{-1}$. Relatively, higher alkalinity values were likewise observed again for Muhib Banda (748 $\mathrm{mg} \mathrm{L}^{-1}$ ), Tarru Jabba (700 $\mathrm{mg} \mathrm{L}^{-1}$ ) and Teteray (720 $\mathrm{mg} \mathrm{L}^{-1}$ ), whereas, the lowest value was observed for Shaidu $\left(250 \mathrm{mg} \mathrm{L}^{-1}\right)$.

Figure 4-5 show a comparison of different parameters of water samples, measured respectively, during 2010 and 2011.

All cations, such as, sodium, calcium and magnesium, analyzed during 2010, were found to be within the permissible limits, ranging from 3.8-69, $0.885-195.6$ and $0.017-2.630 \mathrm{mg} \mathrm{L}^{-1}$. Among the anions, nitrate and phosphate were within the permissible limits, ranging from 0.4-48 and 0.1-0.57 $\mathrm{mg} \mathrm{L}^{-1}$, respectively. However, the anions, such as, chloride and sulfate, were above the permissible limits (Fig. 6). The concentration of chloride ions for samples, collected in 2010, varied from 2-418 $\mathrm{mg} \mathrm{L}^{-1}$. Only two sample locations, namely Nowshera Kalan and Choki Town, showed higher values of chloride. However, samples, collected in 2011, showed normal concentration of chloride ranging from 0-230 $\mathrm{mg} \mathrm{L}^{-1}$. Samples, collected during first phase, showed concentration of sulfate ions ranging from 10-752 $\mathrm{mg} \mathrm{L}^{-1}$. Six sample locations, namely Tarru Jabba, Muhib Banda, Teteray, Khatt Kalay, Nowsher Kalan, Choki Town, showed the highest values of sulfate, while the rest of samples were within the permissible limits (Fig. 6). During the second phase, the concentration ranged from 23-450 mg L $\mathrm{L}^{-1}$, Nowshera Kalan and Khatt Kalay showed the highest values.

Heavy metals: Among the analyzed seven heavy metals (Table 3), zinc, copper and chromium were within safe limits. However, others, such as, iron, nickel, lead and cadmium, were above the permissible limits, during the 


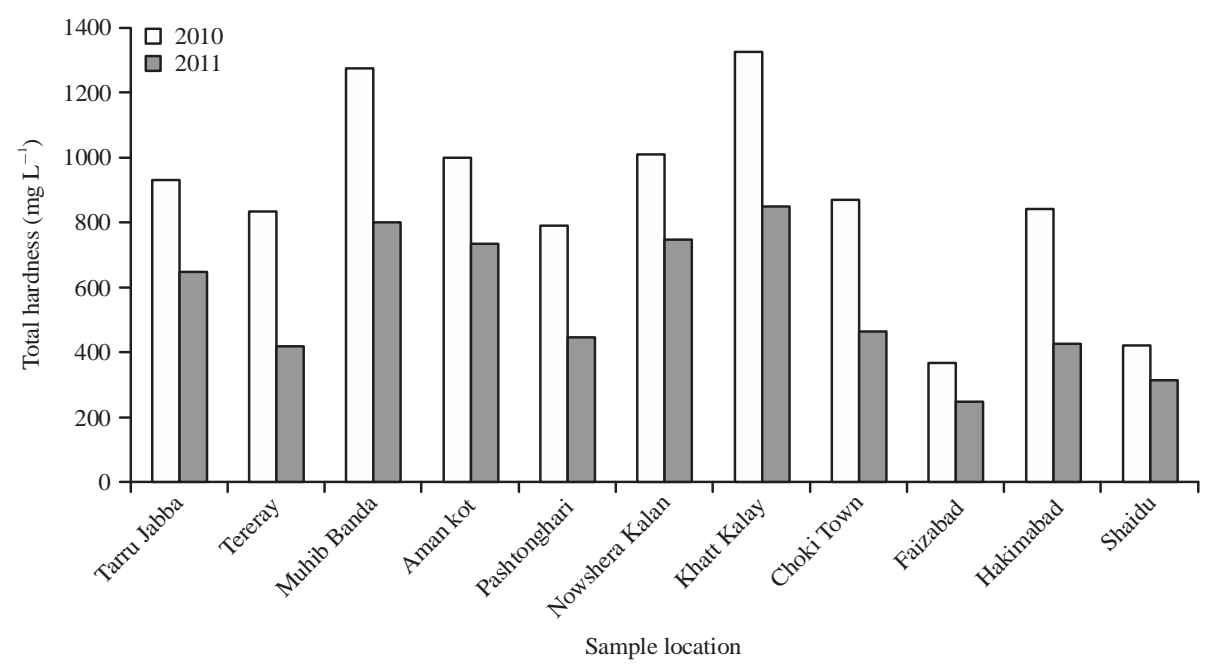

Fig. 5: Comparison of total hardness of water samples of 2010 and 2011

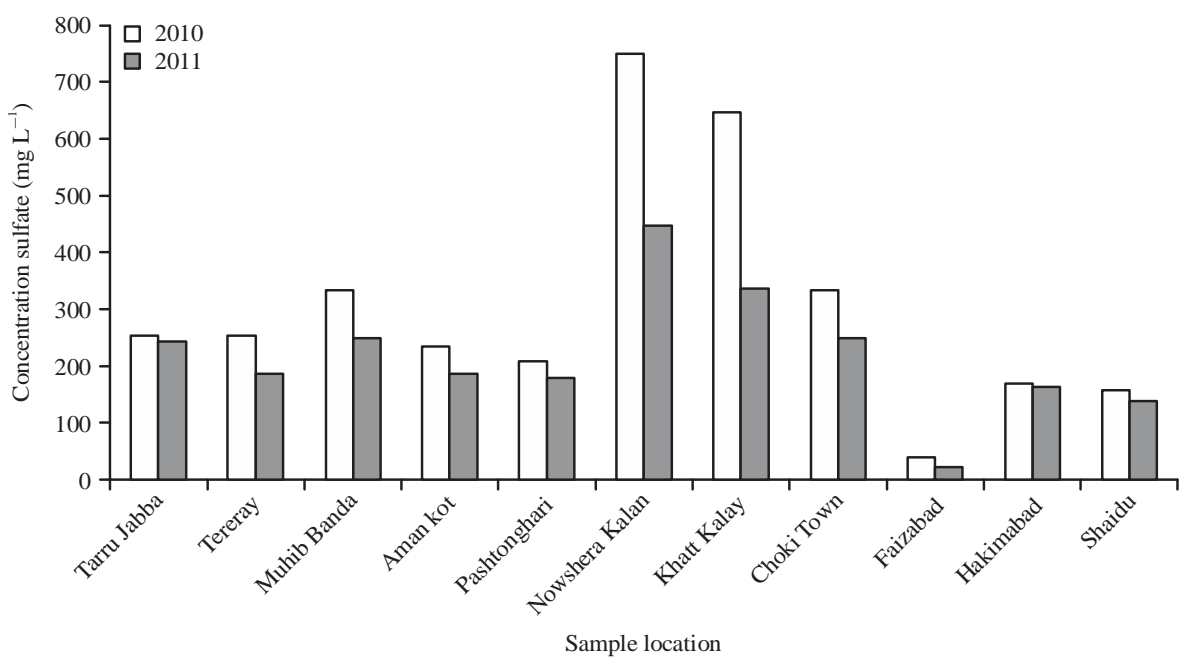

Fig. 6: Comparison of sulfate ions concentration in water samples of 2010 and 2011

first phase of sampling. The concentration of zinc, copper and chromium for samples, collected in 2010, ranged from 0.028-0.861, 0.001-0.047 and 0-0.041 $\mathrm{mg} \mathrm{L}^{-1}$, respectively. Concentration of iron in samples of 2010, ranged from 0.012-0.644 $\mathrm{mg} \mathrm{L}^{-1}$. Azakhel, Nowshera Kalan, Khatt Kalay and Kheshgi showed higher values of iron. Moreover, all samples showed higher values of nickel, varying from $0-0.082 \mathrm{mg} \mathrm{L}^{-1}$, except Nowshera Kalan and Faizabad. The situation changed in 2011, as all samples showed normal values of iron and nickel (from 0.007-0.034 and 0-0.001 $\mathrm{mg} \mathrm{L}^{-1}$, respectively). The concentration of cadmium was found to lie between 0.01-0.028 $\mathrm{mg} \mathrm{L}^{-1}$, in the first phase samples, almost at all sample locations, the concentration was above the permissible limits. Second phase samples showed the values of cadmium, ranging between 0.001 and $0.010 \mathrm{mg} \mathrm{L}^{-1}$, the lowest value $\left(0.001 \mathrm{mg} \mathrm{L}^{-1}\right)$ was observed at Teteray and the highest value $\left(0.01 \mathrm{mg} \mathrm{L}^{-1}\right)$ at Faizabad, Tarru Jabba, Choki Town and Hakimabad. The values of lead in samples, collected in 2010, were above the permissible limits, ranging $0.316-1.134 \mathrm{mg} \mathrm{L}^{-1}$, while the concentration of lead, in second phase samples, was found to vary $0-0.066 \mathrm{mg} \mathrm{L}^{-1}$.

Biological characteristics: Samples, collected in 2010 after two months of flood, were highly contaminated with TCB. Out of twenty-seven samples, only six samples were within the permissible limit of 10/100 mL set by WHO. The TCB observed in the study area, ranging from $0-1800$, the highest number of TCB (1800) was noted for 


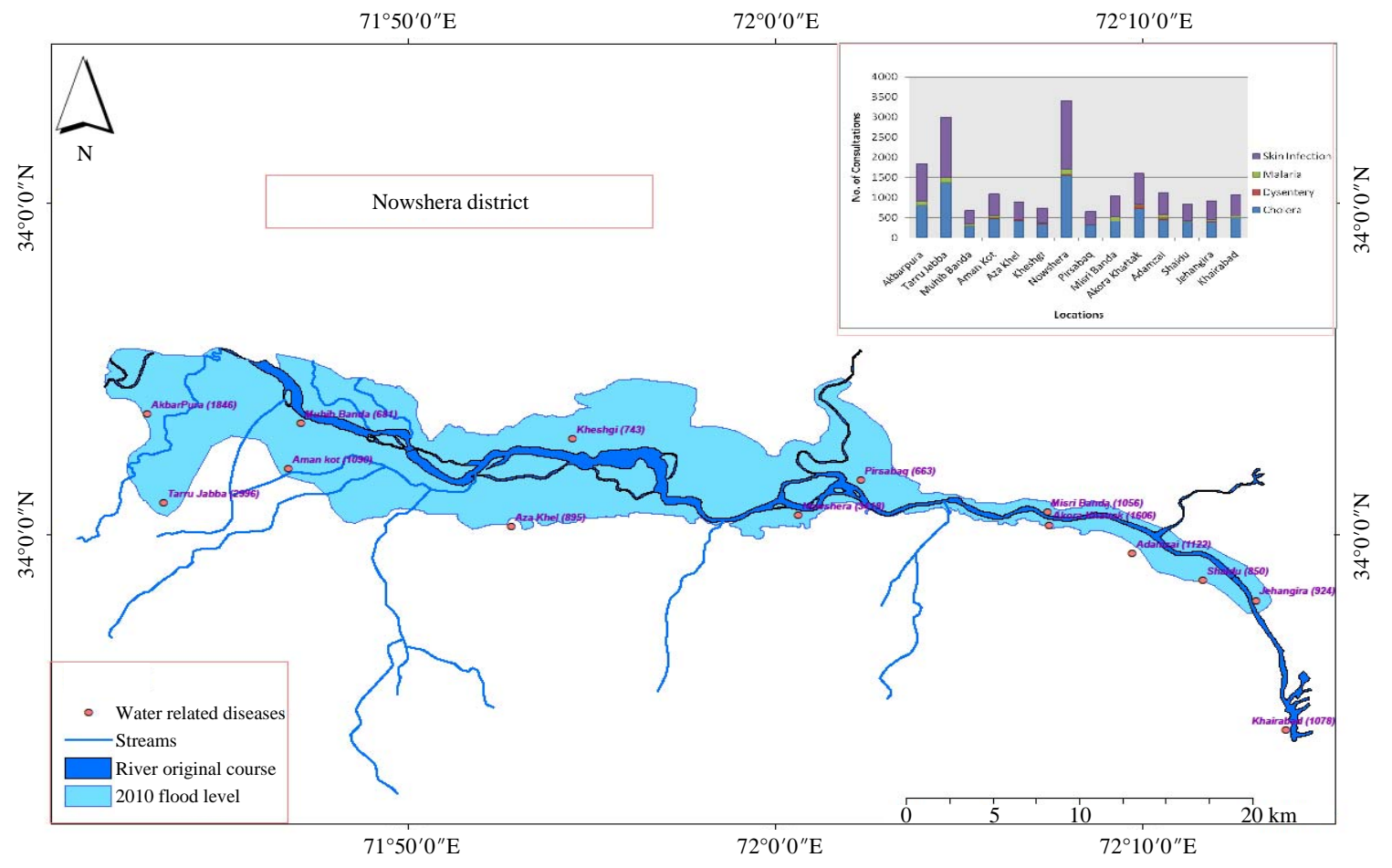

Fig. 7: GIS based map showing locations and total number of cases water related diseases in district Nowshera due to 2010 flood

Aman Kot and Pabbi and the lowest number of TCB (0) was noted for Khairabad. Samples, collected from Pashtonghari, Kheshgi, Adamzai, Jehangira and Kairabad, showed the TCB within permissible limit. TCB in samples, collected in 2011, was ranged from 7-150, the highest value of TCB (150) was noted for Nowshera Kalan and the lowest number of TCB (7) was noted for Hakimabad, Teteray, Faizabad and Khatt Kalay. According to WHO drinking water standards, water having 0 FCB per $100 \mathrm{ml}$ is safe for drinking. All samples, collected in 2010, were above the permissible limit except two points, in which FCB was not present. The FCB in samples, was ranged from $0-1800$, water collected from Pabbi, was highly contaminated with 1800 and the samples, collected from Pashtonghari and Pabbi, was safe for drinking, because FCB was not detected. The values of FCB in samples, collected in 2011, ranged from 0-45. Samples from Teteray, Pashtomghari, Choki Town, Faizabad and Shaidu were safe for drinking, because FCB was not detected, while the highest number of FCB was observed in samples collected from Nowshera Kalan.

Water-borne diseases: Contaminations of drinking water, either directly or indirectly, by human or animal excreta, particularly feces and the use of such water for drinking, preparing food, contact during washing and bathing, results in infection. Cholera, dysentery, gastroenteritis, hepatitis A, typhoid fever and poliomyelitis are some common water-borne diseases, caused by the contaminated and untreated water (Singh et al., 2007).

As such, non-availability of safe drinking water and the lack of medical facilities in the wake of flood were the main causes of subsequent outbreak of water related diseases in the study area. A large number of cases of cholera (acute diarrhea), dysentery (bloody diarrhea), malaria, skin infection and conjunctivitis were widely reported from the affected local community.

The data, collected from the study area by WHO, suggests that 8,634 cases of cholera were recorded in six months after the flood with a majority of cases from Tarru Jabba, Akbarpura and Nowshera. A total of 178 cases of dysentery were reported from different villages of district Nowshera, including Akora Khattak, Jahengira, Adamzai, Pirpai, Aza Khel, Muhib Banda, Aman Kot, Nowshera and Kheshgi. Moreover, 766 cases of malaria were reported from the study area after the flood. Although, higher number of cases were reported from Tarru Jabba, Akbar Pura, Nowshera and Misri Banda. Almost, ten thousand cases $(9,568)$ of skin infection were reported from district Nowshera after the flood of 2010. The highest number of cases were reported from Tarru Jabba and Nowshera (Fig. 7). 
The results, obtained after different analytical procedures, showed that the concentration of some water quality parameters, such as, calcium, phosphate, magnesium, nitrate, zinc, chromium and copper, was within a permissible limit in samples, collected during the first phase. However, the $\mathrm{pH}$ was found to be within safe limit in all samples, collected during both phases, but the concentration of some parameters, including EC, alkalinity, hardness, TDS, TSS, TS, sulfate, iron, chloride, sodium, cadmium, lead, nickel, FCB and TCB, was above the permissible limit in 2010. Although, with the passage of time and infiltration of clean surface water in aquifers after flood, many of the water quality parameters of samples, collected in 2011, returned to their normal condition.

Nearly after two months of flood, water was highly contaminated and all samples showed a higher concentration of EC and TDS. In the first phase of sampling, the concentration of TS was high at some locations, namely, Bhalu, Teteray, Muhib Banda, Aman Kot, Pashtonghari, Nowshera Kalan, Khatt Kalay and Choki Town. However, TS was found within limits in samples collected during second phase after one year, except at Pashtonghari and Nowshera Kalan, which showed high values of TS.

Among the cations and anions nitrate, phosphate, calcium and magnesium were found within permissible limits, during the first phase of sampling. However, most of the samples showed higher values of chloride and sulfate, but after one year, the concentration of these parameters returned to normal, except for Nowshera Kalan and Khatt Kalay, which still showed higher values. In fresh water, high concentration of chloride is regarded as an indicator of pollution because of organic animal waste, inorganic fertilizers, irrigation drainage and industrial effluents (WHO., 1996). The existing data do not identify a level of sulfate in drinking water that is likely to cause adverse human health effects. The presence of sulfate in drinking water may cause dehydration and result in noticeable taste (WHO., 2004). Some of the heavy metals, like, zinc and copper, are essentially required for normal body-growth and functions of living organisms, while high concentration of other metals, like, cadmium, chromium and lead, is considered highly toxic to human (Ouyang et al., 2002). Lead is highly toxic and carcinogenic metal and may cause chronic health risks, including headache, abdominal pain, blood pressure, kidney and lung damages (Steenland and Boffetta, 2000; Jarup, 2003). Iron is a vital component of hemoglobin, which helps red blood cells in carrying oxygen from lungs to body cells and, therefore, its deficiency causes anemia (Peter, 2000). Heavy intake of iron, through extraneous sources, causes nausea, abdominal pain, constipation, intestinal infection and damages to liver and heart (Bhattacharjee, 2001). Cadmium occurs naturally in trace amounts in most foods and, at these levels, causes no harm to human health. Unlike some other metals, such as, copper and zinc, however, cadmium plays no role in human nutrition. Therefore, humans do not require cadmium in their diet and the unlikely event of anyone swallowing large amounts would probably result in unpleasant effects, such as, vomiting, diarrhea and even kidney damage (Barrento et al., 2009).

The concentration of heavy metals including iron, nickel, lead and cadmium, was very high in 2010, but with time, the values changed.

In this study, samples, collected in 2010, were found highly contaminated with TCB and FCB. Although, five sample locations, namely, Tarru Jabba, Pashtonghari, Kheshgi, Jehangira and Khairabad, revealed safe water quality in terms of TCB, but samples from the remaining locations showed significantly polluted water, due to large number of total coliform bacteria in drinking water samples. Similarly, water quality of only two sampling sites, namely, Pashtonghari and Khairabad, was satisfactory from the perspective of fecal coliform bacteria, whereas, all other locations were found to be severely unsafe for human consumption. Subsequent sampling in 2011 revealed that out of 11 sampling sites selected for the second phase, 7 locations still showed unsafe water quality in terms of coliform bacteria.

Overall assessment of all the quality parameters indicates that although the whole of district Nowshera was severely affected by the flood with respect to its groundwater quality, but within one year, most parts of the study area returned to normal values except Nowshera, Pashtonghari, Tarru Jabba and Aman Kot, where almost all the parameters still indicate unsafe water and showed higher number of cases of water-borne diseases, because these locations are populated areas as compared to other locations of the study areas.

\section{CONCLUSION}

The super-flood caused intense damage and destruction to the infrastructure, livestock and population. Besides, the groundwater sources were also highly contaminated, due to infiltration of floodwater into the aquifer. Approximately, all physical, chemical and biological parameters of groundwater were found abnormally high and above the safe limits at all sample locations, rendering it unsuitable for human consumption.

Floodwater carried pathogenic organisms and contaminated groundwater with TCB and FCB, so, the local community faced consequences, including the wide 
occurrence of water-borne diseases, like, cholera, dysentery, malaria and skin infection. One year later, the values of different water quality parameters returned to normal and within safe limits but certain locations, namely, Aman Kot, Nowshera, Pashtonghari and Tarru Jabba, still indicate contamination.

These results show that water becomes contaminated and unfit for the drinking purpose, so there is an urgent need for the arrangement of safe drinking water for the flood affected people. The proactive measures should be taken in regular flooded areas and policy regarding the management of area should be implemented strictly.

\section{REFERENCES}

Abid, H., M.N. Qureshi, J. Ali and Zia-ur-Rehman, 2010. A report on the bacteriological investigation of drinking water of flood 2010 affected areas of Khyber Pakhtunkhwa. Pakistan Council of Scientific and Industrial Research Laboratories (PCSIR), Peshawar, Pakistan.

Ahmad, H., 2009. Environmental Profile of NWFP. 2nd Edn., Government of Pakistan, Pakistan.

Arnold, G.E., S.G. Lenore and O.E. Andrew, 1992. Standard Methods for Examination of Water and Waste Water. 18th Edn., American Public Health Association, Washington, DC.

Barrento, S., A. Marques, B. Teixeira, M.L. Carvalho, P. Vaz-Pires and M.L. Nunes, 2009. Accumulation of elements ( $\mathrm{S}, \mathrm{As}, \mathrm{Br}, \mathrm{Sr}, \mathrm{Cd}, \mathrm{Hg}, \mathrm{Pb}$ ) in two populations of Cancer pagurus: Ecological implications to human consumption. Food Chem. Toxicol., 47: 150-156.

Bhattacharjee, Y., 2001. Excess iron intake increases risk of intestinal infections, study suggests. U.S. Department of Agriculture and The North Carolina Institute of Nutrition. https://researchnews.osu.edu/ archive/iron.htm.

Chitrali, S.Z., 2010. Flood affected areas of Charsadda, Nowshera, Peshawar, Mardan and Swat Districts and response of national rural support program. National Rural Support Program, Islamabad, Pakistan.

Gul, N., 2011. Hydro and pedo-chemistry of Mardan district N.W.F.P, Pakistan with special emphasis on Arsenic contamination. National Center of Excellence in Geology, University of Peshawar, Pakistan.

Islam ud Din, 2011. Hydro-chemical investigation of high altitude alpine lake of Gilgit and Ghizar districts, Northern areas of Pakistan. M.Sc. Thesis, National Center of Excellence in Geology, University of Peshawar, Pakistan.
Jarup, L., 2003. Hazards of heavy metal contamination. Br. Med. Bull., 68: 167-182.

Muhammad, S., M.T. Shah and S. Khan, 2010. Arsenic health risk assessment in drinking water and source apportionment using multivariate statistical techniques in Kohistan region, Northern Pakistan. Food Chem. Toxicol., 48: 2855-2864.

Muhammad, S., M.T. Shah and S. Khan, 2011. Health risk assessment of heavy metals and their source apportionment in drinking water of Kohistan region, Northern Pakistan. Microchem. J., 98: 334-343.

NDMA., 2011. Summary of damages, 14th March 2011. National Disaster Management Authority, Islamabad.

Ouyang, Y., J. Higman, J. Thompson, T. O'Toole and D. Campbell, 2002. Characterization and spatial distribution of heavy metals in sediment from Cedar and Ortega rivers subbasin. J. Contaminant Hydrol., 54: 19-35.

PMD., 2011. Month wise temperature, precipitation and relative humidity of district Nowshera for the years of 2007 and 2010. Pakistan Meteorological Department, Regional Office, Peshawar.

Peter, A.M., 2000. Bioenergenetics and the Metabolism of Carbohydrates and Lipids. In: Harper's Biochemistry, Robert, K.M., K.G. Dary and W.R. Victor (Eds.). 25th Edn., Science Publishing Co., Beijing, China, pp: 182-208.

Rehman, S., 2010. Draft report on flood DNA-2010. Government of Khyber Pakhtunkhwa, Local Government Elections and Rural Development Department, Peshawar.

Singh, K.K., A.K. Singh, A. Juwarkar and A. Tomar, 2007. Air, Water and Soil Pollution. Kalyani Publications, New Delhi, India.

Steenland, K. and P. Boffetta, 2000. Lead and cancer in humans: Where are we now? Am. J. Ind. Med., 38: 295-299.

WHO., 1996. Chloride in Drinking Water. 2nd Edn., World Health Organization, Geneva, Switzerland.

WHO., 2004. Sulfate in drinking water. WHO/SDE/WSH/03.04/114, Background Document for Development of WHO Guideline for Drinking Water Quality, World Health Organization, Geneva. http://www.who.int/water_sanitation_health/dwq/c hemicals/sulfate.pdf 